\title{
VALUE DRIVERS OF PRICE-EARNINGS MULTIPLES OF UNIVERSAL BANKS IN THE PHILIPPINES: A PANEL REGRESSION APPROACH
}

\author{
Antonio J. Dayag ${ }^{1, *}$ and Fernando Trinidad ${ }^{1}$ \\ ${ }^{1}$ The Graduate School, University of Santo Tomas, España, Philippines
}

ABSTRACT - Valuation using P/E multiples has been done mostly in developed countries and some developing countries including the Philippines. However, variables that impact sound P/E multiples valuation has yet to be determined. The purpose of the study is to develop a valuation model using P/E multiples by using variables that will lead to sound valuation of firms. The application would be in the banking sector, specifically universal banks since these institutions are significant economic drivers in the Philippines. Utilizing data from the top ten [10] universal banks in the Philippines in terms of assets and capitalization from 2010 to 2017, selected macroeconomic variables, stock market index, and firm-specific variables were used in the proposed valuation model using panel data regression analysis. These variables are GDP growth rate, inflation rate, interest rate, return on equity [ROE], ROE growth rate, net income growth rate, earnings per share [EPS] growth rate, dividend payout ratio, Philippine Stock Exchange [PSE] index, and price-tobook $[P / B]$ value ratio. Panel regression results showed that among the independent variables, $\mathrm{ROE}, \mathrm{EPS}$ growth rate, $\mathrm{P} / \mathrm{B}$ ratio, net income growth rate, and PSE index are statistically significant. Among the significant variables, ROE reduces P/E ratio by 51 times. This implies that an increasing ROE reduces the price per stock investors are willing to pay. Goodness of fit [R2] of the model is $74.83 \%$, which is relatively good.

ARTICLE HISTORY

Received: 30-12-2018

Accepted: 04-02-2019

KEYWORDS

$P / E$ ratio, Bank valuation,

Panel Regression, P/E

multiples

\section{INTRODUCTION}

A firm's success is judged by its performance over a period of time, just as firms with good performance or profitability are those that will attract investors (Emudainohwo, 2016). Practitioners can compare firms within the same industry or past transactions based on value drivers and calculated multiples. An estimate of its value can be generated and multiples can be applied to the company being investigated. This methodology is applied for fundamental analysis of listed companies, and valuation analysis for unlisted companies during mergers and acquisitions, equity investments, employee stock ownership plans [ESOP] valuations, etc. (Maniar, 2014).

Two major blows in the finance world - the Asian Financial Crisis in 1997, and the Global Financial Crisis in 2008 heavily marred investors' confidence. Investors raised skepticism over truthfulness of financial information issued by businesses. Since informed decision-making is made through valuation, a model that would combine firm-specific and macroeconomic variables offers an alternative to investors in predicting external value drivers, aside from direct calculations using firms' financial statements.

This study focused on banks, particularly universal banks in the Philippines because of its significance in the economy. Corporate governance in banks is significant for economic growth because economic development is driven by a sound and well-functioning banking system (Caprio \& Levine, 2002 as cited in Islam, Sathye, \& Hu, 2015). Since valuation reflects performance, it represents not just the financial framework but gives a snapshot of a bank's corporate governance. Valuation aligns perception of investors about the bank, while a model would validate if the perception is near truth considering external factors that may or may not be within the entities' control. For example, stock markets reward firms with good governance practices and high ethical standards by valuing them high (Baek et al., 2009; Choi \& Jung, 2008; Epstein et al., 1994 as cited in Pae \& Choi, 2010). This is an example of how an external factor cannot be influenced by the firm because the stock market is characterized by complex interrelationships among investors, market, analysts, speculators, and other interested parties

Price-Earnings [P/E] Ratio or P/E Multiple is a commonly utilized stock valuation method frequently discussed in related research papers, academic journals, and on-line articles. P/E ratio indicates how much investors are willing to pay for each currency unit of a firm's earnings. It also reflects investor's confidence and sentiment about a firm's future performance and influences investment decisions. Share price and earnings per share themselves are influenced by accounting inherent, and fundamental factors. 


\section{Statement of the Problem}

At present, there is a low turnout of published studies on this area, especially in developing countries such as the Philippines. To the best knowledge of the author, no study has identified and evaluated P/E ratio value drivers, both along macroeconomic and firm-specific levels.

\section{Objectives of the Study}

Generally, this study aims to determine value drivers of P/E ratio to aid in analyzing stock market performance of universal banks in the Philippines. The rest of the paper is organized in the following order: theoretical framework, review of related literatures, conceptual framework, research method, results, analysis, implications, conclusion, and recommendations.

\section{THEORETICAL FRAMEWORK}

\section{Efficient Market Hypothesis [EMH]}

$\mathrm{P} / \mathrm{E}$ ratio is calculated as the ratio of share market price over earnings per share. One of the theories this research is grounded to is the efficient market hypothesis, an investment theory developed by Eugene Fama that considered to be one of the cornerstones of modern asset pricing for the past 50 years (Fakhry, 2016). One of the most important assumptions of the hypothesis is that no investor may have extraordinary returns using any information (Bayraktar, 2012). The price of securities completely reflects all the existing information in the market; therefore, no investor would obtain differentiated returns.

Efficient market hypothesis explains important characteristics of the stock market and these are (Koller, Goedhart, and Wessels, 2010):

- Share prices more or less are aligned with intrinsic value since informed investors are the market price setters and its boundaries;

- Boundaries for share prices either in the lower or upper limit of the intrinsic value becomes wider when there is uncertainty in the stock's valuation;

- When no new information about the firm has been revealed, share prices can be highly volatile but within the bounds of the limits set by informed investors;

- Deviations in price outside the boundaries set by informed investors using intrinsic valuation happen only in rare situations, such as when informed investors were outnumbered or when institutional barriers hamper selling the stocks

One of the advantages of using multiples (e.g. P/E ratio) is, it assumes the efficient market hypothesis implicitly, and expected future cash flows and discount rates that are market-estimated are indirectly utilized (Kim, 2015). Because of this advantage, estimation of future cash flows and discount rates were able to minimize substantial estimation errors, making multiples be one of the favored valuation models in practice (Kim, 2015).

\section{Dividend Discount Model [DDM]}

The dividend discount model is a valuation theory that looks into growth rate as an important determinant of stock price. This is the oldest valuation model in practice, and the underlying principle is that when investors buy stocks in publicly listings, cash flows from dividends during the holding period and anticipated price at the end of the holding period are expected (Damodaran, 2006). In its most basic form, the formula for Price at the end of the period is given in the following form (Welc, 2011):

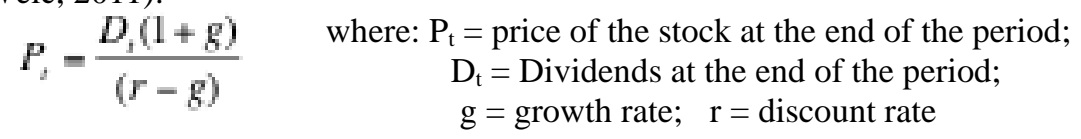

Penman (1997 as cited in Welc, 2011) posited that substituting accrual earnings to cash flows improved accuracy of valuation, therefore, substituting dividends with earnings will change the form to:

$$
P_{t}=\frac{E_{t}(1+g)}{(r-g)}
$$

Dividing both sides of the equation by earnings at time $t\left(E_{t}\right)$ will give PER to be equal to $(1+g) \div(r-g)$. This makes growth rate be an integral component of $\mathrm{P} / \mathrm{E}$ ratio.

In order to maximize shareholders' value, firms need to identify growth drivers and what makes it create value (Koller, Goedhart \& Wessels, 2010). High growth and how it would be sustained is a challenge because innovations have to be introduced in product life cycles. 


\section{Modolovsky Effect}

In 1953, Nicholas Molodovsky's article entitled "A Theory of Price Earnings Ratios" was published in the Financial Analysts Journal (Williams Equity Research, 2015). Molodovsky discovered that P/E ratios were often much higher during depressed points of the business cycle compared to when earnings are higher during peak business cycles (Williams Equity Research, 2015).

\section{LITERATURE REVIEW}

\section{Value Drivers of P/E ratio}

Profitability is one indicator for evaluating firm performance. Profitability measures are fundamental to multiples when measuring risk and return (Pétursson, 2016). Profitability indicators are: return on equity or ROE, return on asset or ROA, asset turnover [ATO] among others. Wu (2014) observed a U-shape relationship between forward P/E ratio and return on equity [ROE]. Besides, the study shows that firms having high P/E ratio tend to have lower ROE in the following years. Moreover, the study by Premkanth (2013) on sample of 30 companies listed on the Colombo Stock Exchange over the period 2007-2011 show that ROE impact negatively on P/E multiple, but not sufficient to explain P/E multiple. Sezgin (2010) observed unidirectional Granger's running from return on equity to P/E ratio. Yuanlong (2012) reexamined a firm's forward $\mathrm{P} / \mathrm{E}$ ratio in relation to expected earnings growth rate. The study revealed that positive correlation exists between PE ratio and the firm's short-term expected earnings growth rate. A positive influence of earnings growth on P/E ratio suggests high earnings growth will offset risk effect and leads to an increase in investors' confidence in $\mathrm{P} / \mathrm{E}$ ratio (Afza \& Tahir, 2012).

The study of Murcia (2014) included macroeconomic variables and the stock market index PSEi as factors that drive the performance of the Philippine Stock Market, while the inclusion of company fundamentals as value drivers were identified in the study of Dawar (2012) on stock pricing of the automotive sector in India. Yuanlong (2012) examined a firm's forward PER relative to EPS growth rate and positive correlation between the PE ratio and the firm's short-term expected earnings growth rate was found.

GDP growth rate is a measure of economic growth. In a Forbes article written by Ferri (2012), the author stated that PER appears to contract when economic growth is slowing, and expands when GDP is expected to expand or grow and inflation is over 6 percent. This analysis was made on a 10-year rolling correlation of GDP growth with P/PeakE, by lagging the latter by 1 year to allow how current valuations are impacted by GDP growth anticipations the next year.

A study conducted on 47 non-financial firms listed at the Nigerian Stock Exchange used quantile and pooled regression models, and found that dividend pay-out ratio is statistically significant to explain P/E ratio at the 25th, 50th and 75 th percentiles. At the 25 th percentile, dividend per share has significant but negative impacts on P/E ratio while dividend payout ratio and total dividend paid has positive significant impacts on $\mathrm{P} / \mathrm{E}$ ratio. At the 50th percentile, dividend payout ratio has significant and positive impacts on $\mathrm{P} / \mathrm{E}$ ratio while dividend per share has significant but negative influence on $\mathrm{P} / \mathrm{E}$ ratio. At the 75th percentile, dividend payout ratio and average share price has positive and significant effects on P/E ratio (Emudainohwo, 2017).

The study of Maniar (2014) showed highest correlation to be observed between price-to- book [P/B] value multiple and Return on Capital Employed [ROCE], followed by ROE and P/B value multiple. ROE and ROCE are measures of capital efficiency and hence could be a proxy for how two companies with same amount of net worth could be differentiated (Maniar, 2014).

The growth rate of earnings per share is computed as the percentage change of a 12-month forward earnings per share relative to the earnings per share of the current year (Huang \& Wirjanto, 2012). Yuanlong (2012) reexamined a firm's forward $\mathrm{P} / \mathrm{E}$ ratio in relation to expected earnings growth rate. The study revealed that positive correlation exists between PE ratio and the firm's short-term expected earnings growth rate. Earnings per share [EPS] is considered an indicator for selecting stocks for investment. A company that is making profit is believed to have higher EPS, and this makes EPS a vital parameter when choosing stocks for investment (Kumar \& Mishra, 2013).

A macro-economic factor involved in determining P/E ratio is inflation. Inflation is defined as a sustained increase in the general level of prices for goods and services. It is measured as an annual percentage increase (Farooq \& Ahmed, 2017). P/E ratio tends to expand when interest rates and inflation decrease while it contracts if otherwise (Timekeeper, 2014). Given that inflation leads to higher variability in prices, it becomes hard for economic agents to detect relevant information from prices (Hsu, Kudo, \&Yamada, 2013). Basu et al. (2010) showed that expected inflation information was not fully incorporated by analysts in their forecasts. Dividend per share [DPS] is the dividends declared by a company divided by the number of outstanding ordinary shares issued. Companies in a better cash position are able to pay dividend, except they have some leverage to inexpensive source of fund.

Perhaps, due to promising information from firms, the relatively more dividend paying firms should be related with relatively higher P/E multiples. However, in an examination of Iran Khodro Company, Mirfakhr, Dehavi, Zarezadeh, Armesh, Manafi \& Zraezadehand (2011) found negative and significant relation between DPS and P/E ratio.

Zucchi (2013 as cited in Sadler, Daghestani \& Payne, 2016) found that high payout ratios indicate the firm is returning cash to the shareholder in the form of dividends, rather than re-investing the profits in the company, and that strong yields, determine the return to the shareholder after all the expenses for operating a business and investment in capital expenditures are spent. Accordingly, both high payout ratios and strong yields may have negative consequences. The 
study concluded that enterprise value per share is the most encompassing and generally considered the most useful in analyzing the current valuation of a stock (Zucchi 2013 as cited in Sadler, et al., 2016).

In a seminal work by Penman (1997 as cited in Smith, 2019), generally high P/Es are associated with high P/Bs, and this generalization was made upon examination of twenty [20] sample portfolios from 1968 to 1985 that were ranked from highest to lowest P/B. Results showed that $66.67 \%$ of the time reveal above-median P/E values are accompanied by above median P/B values (Penman, 1997 as cited in Smith, 2019)

Emudainohwo (2017) examined that dividend growth rate has negative impacts on P/E ratio but results are not sufficient to explain movements in P/E ratio for non-financial firms listed in the New York Stock Exchange [NSE] over the period examined. Although, the results are not sufficient to explain movement in P/E ratio, it however tends to suggest that dividend growth rate is inversely related to P/E ratio, but not moving in the same direction as theoretically expressed.

\section{Synthesis of Literature Review}

Literatures reveal that P/E Multiple has been useful in analyzing stock performance, and with seemingly similar conclusions. Several variables were identified to be influencing P/E ratio. For example, the study of Timekeeper (2014) concluded that P/E multiple tend to expand when the interest rates and inflation decrease, and contracts if otherwise. Dividends and dividend payout ratios were also mentioned to be influencing P/E ratio (Emudainohwo, 2017; Mirfakhr et al., 2011). Most of the studies are on selected firms in stock exchanges and appears to be in varied industries. However, no notable studies that explored P/E Multiple as valuation tool for firms of specific industries were found.

\section{CONCEPTUAL FRAMEWORK}

The choice of the variables interest rates and inflation were derived from the studies of Timekeeper (2014), Farooq \& Ahmed (2017), and Hsu, et al., (2013), while ROE, ROA, and other profitability measures were taken from the studies of Premkath (2013) \& Sezgin (2012). The inclusion of dividend payout ratio as one of the variables was taken from Emudainohwo, (2017). The choice of growth rates of net income, ROE, and EPS to be included in the model was derived from Welc (2011), Koller et al., (2010), \& Yuanlong (2012). The influence of GDP growth rate was taken from Ferri (2012) while the choice of P/B value was from the study of Maniar (2014) on the correlation of P/B value and ROE. The combination of companies' financial fundamentals and macroeconomic variables as possible drivers of P/E ratio was derived from the studies of Murcia (2014), and Dawar (2012). Figure 1 outlines the conceptual framework followed in this study, using the aforementioned variables.

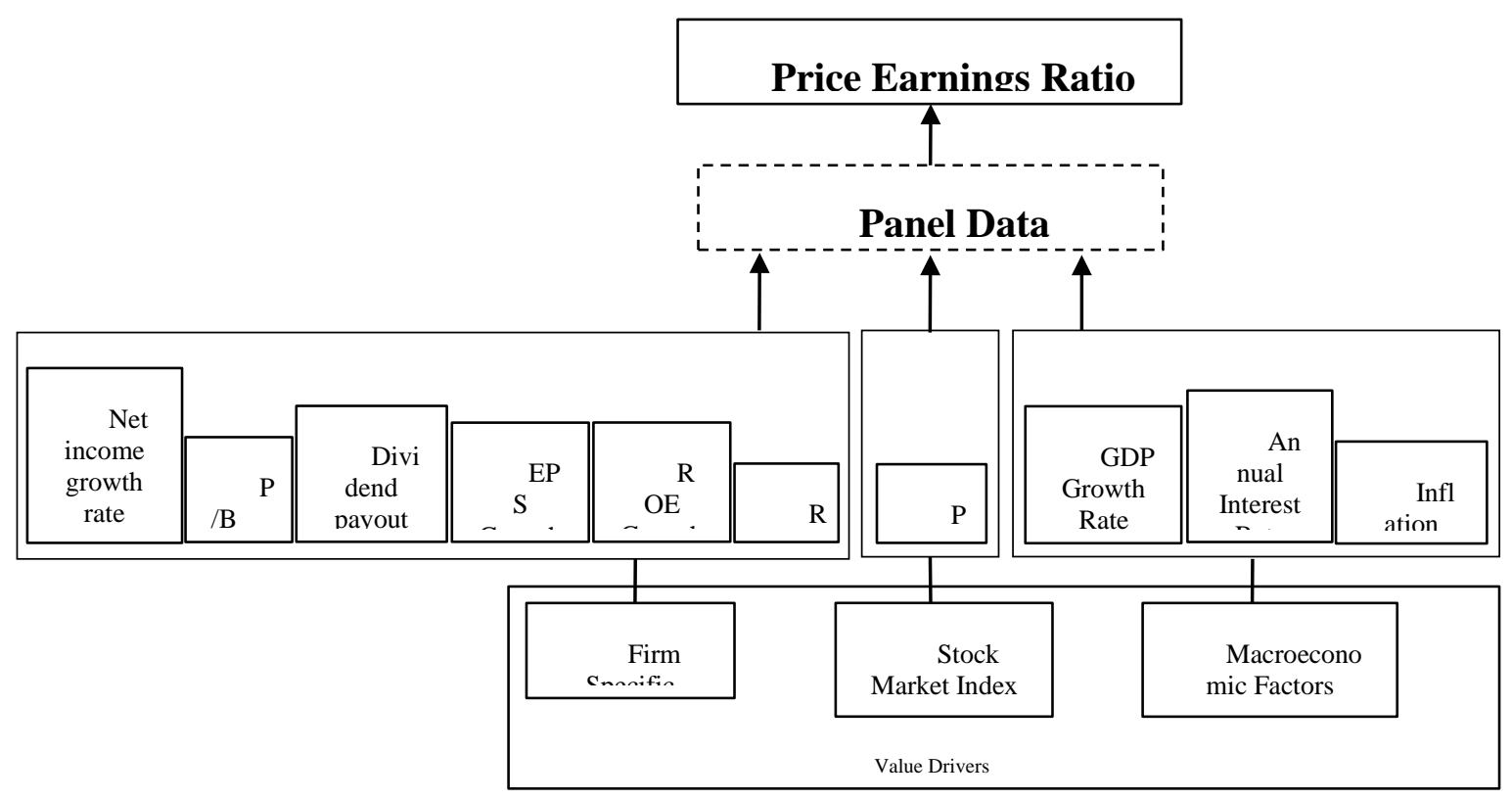

Figure 1: Conceptual Framework

\section{METHODOLOGY}

\section{Research Design}

The study employed panel data analysis. This approach is essential in establishing the theoretical foundation of this study especially the development of the valuation model. Panel data analysis is significant in avoiding heterogeneity of the variables and is performed when there is a need to measure same variables of interest at more than one period of time from the given samples (Salkind, 2010). In performing panel data regression analysis, a choice between fixed effects and random effects can be made depending on the results of these three tests: F-statistics test, Breusch-Pagan test, and Hausman Test. If two out of three test yielded the same results, then the choice of fixed effect or random effect is determined. The equation for fixed effect model is shown as: 


$$
Y_{i t}=\alpha_{i}+\beta_{1} X_{i 1}+\beta_{2} X_{i 2}+\beta_{3} X_{i 3}+\ldots . . \beta_{i t} X_{i t}+\mu_{\text {in }}
$$

And for random effect model, the equation is:

$$
Y_{\text {it }}=\alpha_{i}+\beta_{1} X_{i 1}+\beta_{2} X_{i 2}+\beta_{3} X_{i 3}+\ldots . . \beta_{\text {in }} X_{\text {in }}+\mu_{\text {in }}+\varepsilon_{\text {it }}
$$

Where: $\mathrm{y}_{\mathrm{ij}}$ is the outcome variable (or dependent variable) for a particular ij case

$\beta_{\mathrm{n}}$ are the regression coefficients at time $\mathrm{t}$

$\mathrm{X}_{\mathrm{lt}}$ are regression predictors or independent variables

$\mu_{\text {in }}$ is the "between entity" error

$\varepsilon_{\mathrm{ij}}$ is the "within entity error"

\section{Subjects and Study Sites}

The Philippines is an emerging market and according to Sutedja, Yakob, \& McGowan (2014), emerging markets are attractive investment sites because they offer higher returns than developed markets. The Philippines are among those countries that have returned more than 100\% since the global financial crisis of 2008 (Sutedja et al., 2014). Universal banks are one of the economic drivers in the Philippines. Bangko Sentral ng Pilipinas [BSP] regulates forty-four (44) banks in the country, twenty-one (21) of which are universal banks. Among these, ten [10] universal banks listed in the Philippine Stock Exchange [PSE] were utilized because these banks account for 93\% in terms of capitalization of banks listed in PSE.

The period for this study was from 2010 to 2017. All data are secondary in nature and were collected from the audited financial statements of the selected companies. Macroeconomic variables were also considered in this study as these impact banks' performance.

\section{Research Instruments/Data Measure}

As mentioned, secondary data was used in this study. The data on firm specific variables were generated from the Annual Reports of selected universal banks. The PSE website was the source of information for market price per share and earnings per share to determine the P/E ratio. Moreover, the BSP was the basis in getting the complete list of the banks in the country, particularly the roster of the universal banks. For macroeconomic factors, data was collected from the Philippine Statistics Authority [PSA] database - a compilation of the measures of gross domestic product, inflation rate, and annual interest rate.

\section{Description of the Variables Used}

The dependent variable is $\mathrm{P} / \mathrm{E}$ ratio and is measured as the ratio of the share's current market price over earnings per share.

The independent variables are:

Net Income Growth Rate: This is the percentage change in net income and is calculated as the ratio of the difference between previous period and current period net income over the previous period's net income

Price to Book Value [P/B value] Ratio: This is the ratio of the share's current market price over the book value per share.

Dividend Payout [DPO] Ratio: This is the ratio of dividends paid over net income.

EPS Growth Rate: This is the percentage change in earnings per share and is calculated as the ratio of the difference between previous period and current period earnings per share over the previous period's earnings per share.

Return on Equity [ROE]: This is a portion of net income relative to shareholders' equity

$R O E$ growth rate: This is the percentage change in earnings per share and is calculated as the ratio of the difference between previous period and current period earnings per share over the previous period's earnings per share.

PSEi: This is the index provided by the Philippine Stocks Exchange on a yearly basis.

GDP Growth Rate: This is the percentage change in gross domestic product or GDP and is calculated as the ratio of the difference between previous period and current period gross domestic product over the previous period's gross domestic product. Gross Domestic Product was taken from the Philippine Statistics Authority.

Inflation rate and Interest Rate: This data is provided by the BSP and PSA.

\section{Statistical Treatment of Data}

Descriptive Statistics. The characterization of each variable was determined using mean and standard deviation. In addition, correlation analysis of companies' PER and value drivers, Pearson R correlation was calculated to find out the inter-relationship between variables such as macroeconomic factors, stock market indices, and firm specific variables.

Panel Data Regression. Considering the individuals (banks) and time specifications (eight-year period from 20102017), panel data regression analysis was used in determining the impact and relevant model suitable for the identified value drivers. The main advantage of panel data set over cross section is, it allows researchers greater flexibility in modeling the differences in responses across the samples (Lugano, 2013). Before conducting the panel regression analysis, various tests were conducted to satisfy the assumptions under this approach. These assumptions include normality of distribution, linearity, existence of possible outliers. Goodness-of-fit Kolmogorov-Smirnov test was performed to inspect whether samples obey the normal distribution and the uniform distribution of the P/E ratio. A 
histogram was shown in presenting the normal distribution of PER. Variance Inflation Factor was utilized to confirm issues with multicollinearity. Mahalanobis distance test was executed to determine the outliers among samples.

\section{RESULTS}

\section{Descriptive Statistics and Correlation}

Table 1 shows the descriptive statistics of the dependent variable P/E ratio and the dependent variables. The mean PER is 11.737 and is satisfactory since the data follows a normal distribution (based on the results of the one-sample Kolmogorov-Smirnov [KS] test shown in Appendix 1). The standard deviation is quite high, indicating some levels of variability in the data. This means that banks' $\mathrm{P} / \mathrm{E}$ ratio are independent of each other's performance. Other variables have less variability exhibited.

Table 1: Descriptive Statistics

\begin{tabular}{ccccc}
\hline & Min & Max & Mean & Std. Dev. \\
\hline \hline P/E ratio & 0.5822 & 25.5452 & 11.7374 & 4.7095 \\
ROE & 0.0555 & 0.2818 & 0.1211 & 0.0390 \\
ROE GR & $(0.5095)$ & 1.4293 & 0.0358 & 0.2795 \\
EPS GR & $(0.9237)$ & 1.5938 & 0.0871 & 0.3308 \\
DPO Ratio & 0 & 1.0651 & 0.2587 & 0.2295 \\
P/B value & 0.5486 & 3.7640 & 1.4824 & 0.6877 \\
Net Income GR & $(0.3253)$ & 1.9126 & 0.1757 & 0.3186 \\
PSE index & $4,055.54$ & $7,979.83$ & $6,504.2238$ & $1,220.1625$ \\
Inflation Rate & 0.7000 & 4.7000 & 2.8500 & 1.2376 \\
GDP GR & 3.6600 & 7.6320 & 6.3516 & 1.1258 \\
Interest Rate & 2.3000 & 6.2000 & 3.5990 & 1.1194 \\
\hline
\end{tabular}

Table 2 shows the correlation coefficients of each variable relative to other variables using Pearson Correlation. Most of the variables are weakly correlated except for $\mathrm{P} / \mathrm{B}$ value ratio and $\mathrm{P} / \mathrm{E}$ ratio with a value of 0.6. This is expected since the same market share price is used. Similarly, ROE growth rate and EPS growth rate are strongly positively correlated at 0.7 because earnings per share are related to net income. Net income growth rate is positively correlated with ROE growth rate and EPS growth as these growth rates refer to the same net income. Even with several levels of positive correlation, the following assumption tests to proceed with multiple regression were still met. Linearity is observed among pairs of variables with asterisk (*). Other tests for normality using Kolmogorov-Smirnov, and test for outliers using variance inflation factor [VIF] were all met. (See appendices 1-3).

Table 2: Correlation Matrix

\begin{tabular}{|c|c|c|c|c|c|c|c|c|c|c|c|}
\hline & $\begin{array}{l}\mathrm{P} / \mathrm{E} \\
\text { ratio }\end{array}$ & ROE & $\begin{array}{l}\text { ROE } \\
\text { GR }\end{array}$ & $\begin{array}{l}\text { EPS } \\
\text { GR }\end{array}$ & $\begin{array}{l}\text { DPO } \\
\text { ratio }\end{array}$ & $\begin{array}{l}\text { PBV } \\
\text { ratio }\end{array}$ & $\begin{array}{l}\text { Net } \\
\text { Income } \\
\text { GR }\end{array}$ & $\begin{array}{l}\text { PSEi } \\
\text { index }\end{array}$ & $\begin{array}{l}\text { Inflation } \\
\text { Rate }\end{array}$ & $\begin{array}{l}\text { GDP } \\
\text { GR }\end{array}$ & $\begin{array}{l}\text { Interest } \\
\text { Rate }\end{array}$ \\
\hline $\mathrm{P} / \mathrm{E}$ ratio & 1 & & & & & & & & & & \\
\hline ROE & $(0.3)^{* *}$ & 1.0 & & & & & & & & & \\
\hline ROE GR & $(0.3)^{*}$ & $0.4 * *$ & 1.0 & & & & & & & & \\
\hline EPS GR & $(0.2)$ & $0.4^{* *}$ & $0.7 * *$ & 1.0 & & & & & & & \\
\hline $\begin{array}{l}\text { DPO } \\
\text { Ratio }\end{array}$ & $0.3^{* *}$ & 0.2 & 0.0 & $(0.1)$ & 1.0 & & & & & & \\
\hline $\begin{array}{l}\mathrm{P} / \mathrm{B} \text { value } \\
\text { Ratio } \\
\text { Net }\end{array}$ & $0.6^{* *}$ & 0.1 & $(0.1)$ & $(0.0)$ & $0.4^{* *}$ & 1.0 & & & & & \\
\hline $\begin{array}{l}\text { Income } \\
\text { GR }\end{array}$ & $(0.2)$ & $0.4^{* *}$ & $0.7^{* *}$ & $0.8^{* *}$ & $(0.1)$ & $(0.1)$ & 1.0 & & & & \\
\hline PSE index & $0.3^{* *}$ & $(0.4)^{* *}$ & $(0.3)^{* *}$ & $(0.2)$ & $(0.0)$ & $(0.1)$ & $(0.3)^{* *}$ & 1.0 & & & \\
\hline $\begin{array}{l}\text { Inflation } \\
\text { Rate }\end{array}$ & $(0.1)$ & 0.4 & 0.1 & 0.0 & 0.0 & 0.2 & 0.1 & $(0.6)^{* *}$ & 1.0 & & \\
\hline GDP GR & 0.1 & $(0.1)$ & 0.2 & $0.3 * *$ & 0.0 & 0.0 & 0.2 & 0.2 & $(0.4)^{* *}$ & 1.0 & \\
\hline $\begin{array}{l}\text { Interest } \\
\text { Rate }\end{array}$ & 0.0 & $(0.2)$ & 0.0 & $(0.0)$ & 0.0 & $(0.1)$ & $(0.1)$ & $0.3^{* *}$ & $(0.9)$ & 0.2 & 1.0 \\
\hline
\end{tabular}

$\mathrm{GR}=$ growth rate 
Fixed or Random Effects

F-statistics Test:

Joint significance of differing group means:

$\mathrm{F}(9,58)=10.5392$ with p-value $1.84998 \mathrm{e}-09$

(A low p-value counts against the null hypothesis that the pooled OLS model is adequate, in favor of the fixed effects alternative.

Breusch-Pagan test

Null hypothesis: Variance of the unit-specific error $=0$

Asymptotic test statistic: Chi-square $(1)=62.5956$ with p-value $=2.53826 \mathrm{e}-15$. (A low p-value counts that the null hypothesis that random effect is not appropriate, in favor of the fixed effects alternative.)

Hausman test

Null hypothesis: GLS estimates are consistent

Asymptotic test statistic: Chi-square $(8)=7.80772$ with $\mathrm{p}$-value $=0.452475$. (A high p-value counts against the null hypothesis that the pooled OLS model is adequate, in favor of the random effects alternative.)

The results of the three tests showed fixed effects to be the favored alternative.

Panel Regression Results

Table 3 shows the panel regression analysis containing the coefficients and significant at $\alpha=0.5$ using Gretl software. Variables in blackened fonts are the significant variables.

Table 3: Panel Regression Results

\begin{tabular}{lcccc}
\hline & coefficient & std. error & t-ratio & p-value \\
\hline \hline const & 5.3251 & 1.9817 & 2.6871 & 0.02491 \\
ROE & $(51.365)$ & 5.4868 & $(9.3616)$ & 0.000006 \\
ROE GR & 1.9413 & 1.5121 & 1.2838 & 0.23126 \\
EPS GR & $(6.984)$ & 1.6307 & $(4.2829)$ & 0.00204 \\
Dividend Payout & 0.5285 & 4.1881 & 0.1262 & 0.90234 \\
Ratio & 3.6503 & 0.5383 & 6.7805 & 0.00008 \\
P/B Ratio & 6.5615 & 2.3704 & 2.7680 & 0.02182 \\
Net Income GR & 0.0012 & 0.0002 & 4.3210 & 0.00193 \\
PSEindex & $(0.0683)$ & 0.2021 & $(0.3381)$ & 0.74300 \\
GDP GR & $(0.2536)$ & 0.1330 & $(1.9068)$ & 0.08890 \\
Interest Rate & & & \\
\hline
\end{tabular}

Goodness of fit measurement of the regression model $\left(\mathrm{R}^{2}=0.74834\right.$ or $\left.74.83 \%\right)$ is shown in Table 4 , which shows a good fit.

Table 4: Goodness of Fit

\begin{tabular}{lc}
\hline Test & Score \\
\hline \hline S.D. dependent var & 4.618149189 \\
S.E. of regression & 1.920039519 \\
Within R-squared & 0.748344315 \\
Akaike criterion & 335.1588769 \\
Hannan-Quinn & 352.9714068 \\
Durbin-Watson & 1.061888369 \\
\hline
\end{tabular}

\section{DISCUSSION}

Significant variables are found to be those with p-values that are less than the significance level of 0.05 and these are: ROE with $p$-value $=0.000006$, EPS growth rate with $\mathrm{p}$-value $=0.002041, \mathrm{P} / \mathrm{B}$ ratio with $\mathrm{p}$-value $=0.000081$, Net income growth rate with $\mathrm{p}$-value $=0.021823$, and PSEi with $\mathrm{p}$-value $=0.001930$. The other variables $-\mathrm{ROE}$ growth rate, (p-value $=0.23126)$, dividend payout ratio $(\mathrm{p}$-value $=0.90234)$, GDP growth rate $(\mathrm{p}$-value $=0.743)$, and interest rate $(\mathrm{p}$-value $=$ 0.08890) do not significantly impact Philippine universal banks' PER.

The coefficient of ROE is -51.365 , which means that as ROE increases, P/E ratio declines by a factor of 51.365. ROE negatively impacts PER, and this is similar to the findings of Premkath (2013) \& Sezgin (2012). Net income growth rate and EPS growth rate positively influence PER, and is consistent with the study of Yuanlong (2012). The inclusion of P/B ratio as a significant value driver is concluded to be an added feature of this regression model for $\mathrm{P} / \mathrm{E}$ ratio of universal banks, which is similar to the study of Maniar (2014). As expected, PSE index influences P/E ratio because stock markets dictate price of stocks. ROE negatively impacts $\mathrm{P} / \mathrm{E}$ ratio by a large amount, and this is same with the findings of 
Premkanth (2013). However, in previous studies, ROE is not statistically significant while this study's result showed that it is statistically significant.

The inverse relationship between ROE and P/E ratio is explained by the reversal effect, or the Molodovsky effect, based on literature. Assuming that the variables share price, outstanding number of shares, and shareholders equity are kept constant, while net income is varied, Table 5 illustrates scenarios showing the impact of increase or decrease on net income on ROE and $\mathrm{P} / \mathrm{E}$ ratio. When banks' ROE increase, $\mathrm{P} / \mathrm{E}$ may decline assuming market price keeps minimum volatility or are kept at some steady trend. On the other hand, when banks' ROE decrease, P/E increases. It implies that an increase in ROE is not favorable because P/E ratio declines. It means that when ROE increases, the price that investors are willing to pay per unit of share declines.

Table 5: Illustration of the Reversal Effect

\begin{tabular}{|c|c|c|c|}
\hline Given: & Year 2018 & Year 2019 & Remarks \\
\hline Market Price & 100 & 100 & \\
\hline Equity & $10,000,000$ & $10,000,000$ & \\
\hline Shares outstanding & 100,000 & 100,000 & \\
\hline Scenario 1: Net Income decreases & Year 2018 & Year 2019 & \\
\hline Net Income & $1,000,000$ & 800,000 & \\
\hline EPS (Net income / shares outstanding) & 10 & 8 & \\
\hline ROE (Net income / equity) & $10 \%$ & $8 \%$ & ROE decrease \\
\hline P/E ratio (Market price / EPS) & 10 & 12.50 & $\mathrm{P} / \mathrm{E}$ ratio increase \\
\hline Scenario 2: Net Income increases & Year 2018 & Year 2019 & \\
\hline Net Income & $1,000,000$ & $1,200,000$ & \\
\hline EPS (Net income / shares outstanding) & 10 & 12 & \\
\hline ROE (Net income / equity) & $10 \%$ & $12 \%$ & ROE increase \\
\hline P/E ratio (Market price / EPS) & 10 & 8.33 & $\mathrm{P} / \mathrm{E}$ ratio decrease \\
\hline
\end{tabular}

The inverse relationship between EPS and P/E ratio can be mathematically explained since EPS is in the denominator of $\mathrm{P} / \mathrm{E}$ ratio calculation. When EPS declines, $\mathrm{P} / \mathrm{E}$ ratio increases, and vice-versa.

Net income positively impacts $\mathrm{P} / \mathrm{E}$ ratio since a unit increase in net income increases $\mathrm{P} / \mathrm{E}$ ratio by a factor of 3.65 . However, an increase in net income increases ROE, ceteris paribus, and as shown in the reversal effect may ultimately decrease overall $\mathrm{P} / \mathrm{E}$ ratio. This means that the significant impact of net income can be due to its influence on ROE and $\mathrm{P} / \mathrm{E}$ ratio.

$\mathrm{P} / \mathrm{B}$ value positively impacts $\mathrm{P} / \mathrm{E}$ ratio and generally, and based on literature, high $\mathrm{P} / \mathrm{E}$ ratios are associated with high $\mathrm{P} / \mathrm{B}$ ratios (Penman, 1997 as cited in Smith, 2019).

\section{CONCLUSION, IMPLICATIONS, AND RECOMMENDATIONS}

The study developed a P/E model for universal banks in the Philippines using a combination of macroeconomic, firmspecific, and stock market index as variables. The panel regression analysis found that important value drivers for PER of universal banks in the Philippines are ROE, P/B ratio, EPS growth rate, Net Income Growth Rate, and PSE index. However, macroeconomic variables do not significantly impact $\mathrm{P} / \mathrm{E}$ ratio.

One of the major implications of the result of this study is with regards to the significant and negative coefficient of ROE that showed its inverse relationship with P/E ratio. An increasing ROE is a strong indicator of efficient management of equity since higher return means shareholders' equity is utilized effectively to generate sales. On the other hand, rising ROE may signal decline in P/E ratio, which in effect, reflects how investors view the impact of the firm's governance. From this perspective, rising ROE may not be that attractive to investors. Managers may interpret increasing ROE as a reflection of how well the business was managed, but in the viewpoint of investors, this may not be the case. Nevertheless, there are some recommended measures that the business can take. First, when ROE is on an increasing trend, the business may reduce the number of shares outstanding so that EPS will decline, and P/E ratio will rise, assuming that market price of stock fluctuates very little. Second, when ROE increases, the business may introduce measures that will increase their value in the market. For example, the business may intensify launch of new products or new features on existing products that could help boost company image in the general public. When there is an increase in demand on products or services the business offers, it is likely that share price will rise in the stock market. Another is to engage in aggressive corporate social responsibility [CSR] and sustainability initiatives that will have meaningful impact to stakeholders, though 
engagement in non-revenue activities does not assure rise in revenues. Such initiatives may have more long-term effects. And based on literature readings earlier, stock markets reward firms with good governance practices and high ethical standards by valuing them high (Baek et al., 2009; Choi \& Jung, 2008; Epstein et al., 1994 as cited in Pae \& Choi, 2010). In this case, good governance, CSR, sustainability initiatives, and high ethical standards help in increasing P/E ratio.

Emerging market valuation of universal banks are complex and applicability of valuations depend on information available. There is a need to create some consistent set of macroeconomic assumptions that depend on the type of industry. A distinct characteristic that differentiates emerging and developed markets is, the former has higher levels of risk. Universal banks are complex to value because these entities engage in wide range of activities. These banks have many revenue generating resources in the form of interest income. The diversity and cyclicality of universal banks make valuation a sensitive undertaking. This implies that the use of P/E multiples can also demonstrate flaws, but nevertheless, the choice of independent variables used in this study resulted to a good regression model, which investors can use in deriving P/E ratio of universal bank(s) of choice, compare with peers and industry benchmarks, and develop meaningful valuation. The scope of products and services of universal banks are the same but each bank has different approaches that make them competitive. As universal banks become significant players in the emerging economy of the Philippines, valuation is important because it reflects investors' trust and confidence in the overall banking system of the country, and ultimately how corporate governance is practiced in the banks' day-to-day operations. This study is timely because banks nowadays are under tighter scrutiny and stricter regulations as compared to how it was historically. Moreover, banks all over the world are still in a slow pace of renewing investors' confidence because of the severe uncertainty brought by the financial shocks of 1997 and 2008.

\section{ACKNOWLEDGEMENT}

This researcher humbly expresses deepest gratitude first and foremost to God for the wisdom and strength to pursue this academic undertaking, family, relatives, and close friends for their unending support and understanding; and professional colleagues in and outside the University of Santo Tomas who unselfishly shared time and expertise in the field of finance and investments, academic research, and presentation.

\section{REFERENCES}

Caccese, J. B., Buckley, T. A., Tierney, R. T., Arbogast, K. B., Rose, W. C., Glutting, J. J., \& Kaminski, T. W. (2018). Head and neck size and neck strength predict linear and rotational acceleration during purposeful soccer heading. Sports Biomechanics, 17(4), 462-476. https://doi.org/10.1080/14763141.2017.1360385

Huang, X., Sun, J., \& Sun, J. (2018). A car-following model considering asymmetric driving behavior based on long short-term memory neural networks. Transportation Research Part C: Emerging Technologies, 95(February), 346-362. https://doi.org/10.1016/j.trc.2018.07.022

James, S. L., Abate, D., Abate, K. H., A Afza, T., \& Tahir, S. (2012). Determinants of price-earnings ratio: The case of chemical sector of Pakistan. International Journal of Academic Research in Business and Social Sciences, 2(8), 331- 343.

Basu, S., Markov, S., \& Shivakumar, L. (2010). Inflation, earnings forecasts, and post-earnings announcement drift. Rev. Accounting Stud., 15(2), 403-440.

Bayraktar, B. (2012). Etkin piyasalar hipotezi, T. C. Aksaray Üniversitesi İ.İ.B.F. Dergisi, 3(1), 37-46.

Damodaran, A. (2006). Damodaran on Valuation (2nd Edition ed.), New York: John Wiley \& Sons Inc.

Emudainohwo, O. B. (2016). Firm Size and Firms' Performance: Evidence from non-Financial Service Industries in Nigeria. Ilorin Journal of Management Science, 3(1), 1-17.

Emudainohwo, O. B. (2017). Determinants of Price-Earnings Ratio: Nigerian Experience (Quantile Regression). International Journal of Economics, Business and Management Research, 1(5).

Fakhry, B. (2016). A Literature Review of the Efficient Market Hypothesis. Turkish Economic Review, 3(3), 431-442

Farooq, O., \& Ahmed, N. (2018). Does inflation affect sensitivity of investment to stock prices? Evidence from emerging markets. Finance Research Letters, 2 (5), 160-164. doi:10.1016/j.frl.2017.10.019

Ferri, R. (2012). A second look at P/E ratios (Part II). Forbes. Retrieved from: https://www.forbes.com/sites/rickferri/2012/10/25/asecond-look-at-pe-ratios-part-ii/\#f05eea08027d

Hsu, J., Kudoh, H., \& Yamada, T. (2013). When sell-side analysts meet high-volatility stocks: an alternative explanation for the lowvolatility puzzle. J. Invest. Manage, 2, 28-46.

Huang, A., \& Wirjanto, T. (2012). Is China's P/E ratio too low? Examining the role of earnings volatility. Pacific-Basin Finance Journal, 20(1), 41-61.

Islam, J., Sathye, M., \& Hu. H. (2015). Examining the relationship between corporate governance and bank performance in Bangladesh. South Africa Journal for Business Management, 46(4). doi:10.4101/sajbm.v46i4.108.

Lugano. (2013). Chapter 11 - Models for Panel Data. Greene, 373-464

Kim, J. (2015). Improving practices of price and earnings estimations. Thesis. University of Edinburgh, 1-173.

Koller, T., Goedhart, M., and Wessels, D. (2010). Valuation: Measuring and Managing the Value of Companies. New Jersey: John Wiley \& Sons Inc.

Kumar, R., \& Mishra, S. (2013). Impact of fInancIal IndIcators on BSE SENSEX. Journal of Commerce and Accounting Research, 2(4), 51-56.

Maniar, B. (2014). Factors Influencing Pricing Multiples in India. The IUP Journal of Applied Finance, 20(1), 23-33.

Mirfakhr, S., Dehavi, H., Zarezadeh, E., Armesh, H., Manafi, M., \& Zraezadehand, S. (2011). Fitting the relationship between financial variables and stock price through fuzzy regression case study: Iran Khodro Company. International Journal of Business and Social Science, 2(11), 140-146.

Murcia, J. (2014). Macroeconomic estimation of selected Philippine Stock Market Indices. Southeast Asian Interdisciplinary Research 
Journal, 2, 21-30.

Pae, J., \& Choi, T.H. (2010). Corporate governance, commitment to business ethics and firm valuation: evidence from Korean stock market. Journal of Business Ethics, 100, 323-348 doi:10.1007/s10551-010-0682-z.

Pétursson, E. (2016). Relative valuation - Accuracy of Corporate Valuation Using Multiples. Lund University, School of Economics and Management. Lund University Publications Student Papers.

Plenborg, T. \& Pimentel, R. (2016). Best practices in applying multiples for valuation purposes. The Journal of Private Equity

Premkanth, P. (2013). Determinants of Price Earning Multiple in Sri Lanka Listed Companies. European Journal of Business and Innovation Research, 1(2), 44-56

Rostan, P., \& Rostan, A. (2012). Assessing the predictive power of customer satisfaction for financial and market performance: Priceto-earnings ratio is a better predictor overall. International Review of Management and Marketing, 2(1), 59-74.

Sadler, A., Daghestani, A., \& Payne, B.C. (2016). A risk return profile and ranking of the determinants of the enterprise multiple. Academy of Accounting \& Financial Studies Journal, 20(1), 93-102

Salkind, N. Encyclopedia of Research Design (Vol. 2). *: SAGE Publications, Inc

Sezgin, F. (2010). An empirical investigation of the relationship among P/E ratio, stock returns and dividend yields for Instanbul Stock Exchange. International Journal of Economic and Finance Studies, 2(1), 15-23.

Smith, D. (2019). The articulation of Price-Earnings ratios and market-to-book ratios and the evaluation of growth (Digest Summary). CFA Institute. Retrieved from: https://www.cfainstitute.org/research/cfa-digest/1997/05/the-articulation-of-priceearningsratios-and-market-to-book-ratios-and-the-evaluation-of-growt

Sutedja, B.,Yakob, N., \& McGowan Jr., C. (2014). Relative valuation approach for valuing equity in Malaysia. Handbook of Asian Finance, 2, 2017-223. doi:10.1016/B978-0-12-800986-4.00011-X

Tabara, N., \& Vasiliu, A. (2011). Antoine-Laurent de Lavoisier: a precursor of national accounting. EuroEconomica, 5. Retrieved from: http://journals.univ-danubius.ro/index.php/euroeconomica/article/view/1145/96

Timekeeper. (2014). "Are Stocks Overpriced? A Smart Bull and a Smart Bear Answer the Big Question.” CNN Money.

Welc, J. (2011). Do fundamentally-adjusted valuation multiples improve valuation accuracy? The case of the Polish Stock Market. Accounting and Taxation, 3,(1), 55-70

Williams Equity Research. (2015). The Molodovsky Effect: A better understanding of the P/E ratio. Seeking Alpha. Retrieved from: https://seekingalpha.com/article/3500726-molodovsky-effect-better-understanding-p-e-ratio

Wu, W. (2014). The P/E ratio and Profitability. Journal of Business and Economics Research,12(1), 67-76.

Yuanlong, H. (2012). Relationship between firm's P/E ratio and earnings growth rate. University of Cincinnati UMI Dissertation Publishingbay, S. M., Abbafati, C., Abbasi, N., Abbastabar, H., Abd-Allah, F., Abdela, J., Abdelalim, A., Abdollahpour, I., Abdulkader, R. S., Abebe, Z., Abera, S. F., Abil, O. Z., Abraha, H. N., Abu-Raddad, L. J., Abu-Rmeileh, N. M. E., Accrombessi, M. M. K., ... Murray, C. J. L. (2018). Global, regional, and national incidence, prevalence, and years lived with disability for 354 diseases and injuries for 195 countries and territories, 1990-2017: a systematic analysis for the Global Burden of Disease Study 2017. The Lancet, 392(10159), 1789-1858. https://doi.org/10.1016/S0140-6736(18)32279-7

Tan, H., Qin, L., Jiang, Z., Wu, Y., \& Ran, B. (2018). A hybrid deep learning based traffic flow prediction method and its understanding. Transportation Research Part C: Emerging Technologies, 90(January), 166-180. https://doi.org/10.1016/j.trc.2018.03.001

Taylor, K., Post, A., Hoshizaki, T. B., \& Gilchrist, M. D. (2019). The effect of a novel impact management strategy on maximum principal strain for reconstructions of American football concussive events. Proceedings of the Institution of Mechanical Engineers, Part P: Journal of Sports Engineering and Technology, 233(4), $503-513$. https://doi.org/10.1177/1754337119857434

\section{APPENDICES}

Appendix 1: Kolmogorov-Smirnov Test

\begin{tabular}{lllllll}
\hline \multicolumn{7}{c}{ Tests of Normality } \\
\hline & \multicolumn{7}{c}{ Kolmogorov-Smirnov ${ }^{\mathrm{a}}$} & Shapiro-Wilk \\
\cline { 2 - 6 } & Statistic & df & Sig. & Statistic & df & Sig. \\
\hline PER & .052 & 80 & $.200^{*}$ & .991 & 80 & .859 \\
\hline \multicolumn{7}{l}{ *. This is a lower bound of the true significance. } \\
\hline
\end{tabular}




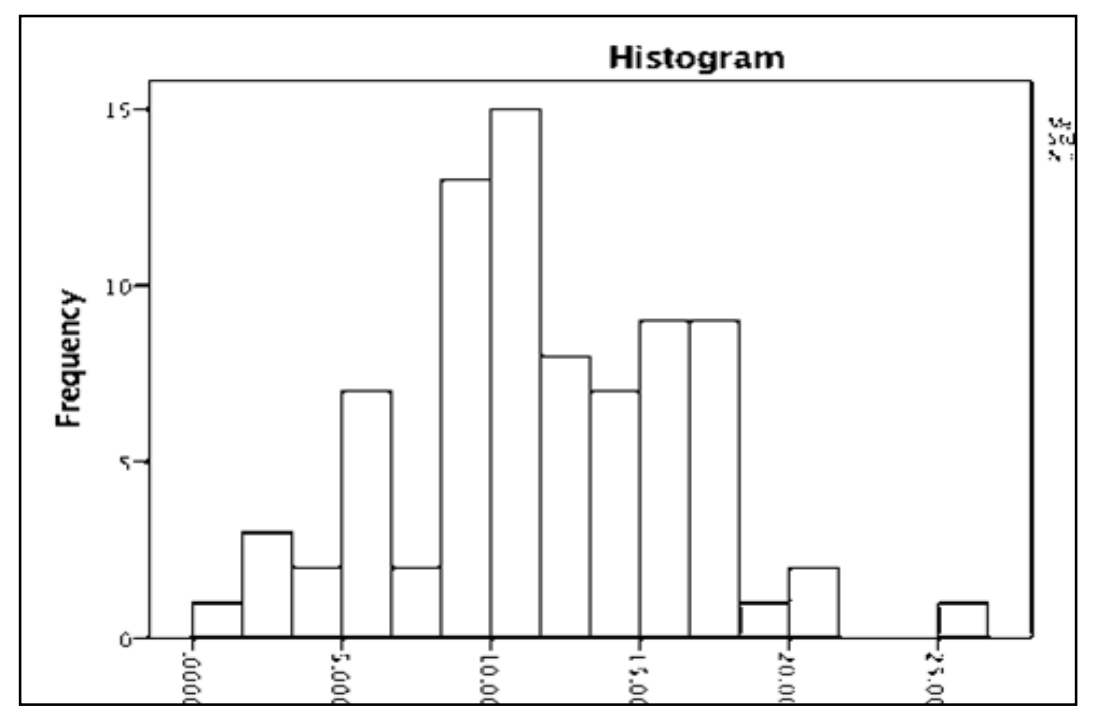

Appendix 1 shows the normality of distribution that was determined by testing the null hypothesis that the data is normally distributed. If the p-value using Kolmogorov-Smirnov test is less than 0.05 , then the null hypothesis is rejected. Our data showed that $\mathrm{p}$-value is $0.200(\mathrm{p}>0.05)$ therefore we accept the null hypothesis that the dependent variable is normally distributed. The accompanying histogram chart depicted the distribution of the data that confirmed normality of distribution.

\section{Appendix 2: Test for Multicollinearity -Variance Inflation Factor [VIF]}

Appendix 2 shows variables with VIF values less than 10 that are considered acceptable for absence of multicollinearity. Except for inflation rate, the rest of the variables were considered in the regression analysis. Since inflation rate's VIF is 10.3, this researcher decided to still include this variable since it is a little close to 10, and several literatures such as the studies of Clarke (2014), Farooq \& Ahmed (2017), and Hsu, Kudo \& Yamada (2013), demonstrated the importance of inflation rate as one of the value drivers of PER.

Coefficients $^{\mathbf{a}}$

\begin{tabular}{|c|c|c|c|c|c|c|c|}
\hline \multirow[b]{2}{*}{ Model } & \multicolumn{2}{|c|}{$\begin{array}{l}\text { Unstandardized } \\
\text { Coefficients }\end{array}$} & \multirow{2}{*}{$\begin{array}{l}\text { Standardized } \\
\text { Coefficients } \\
\text { Beta }\end{array}$} & \multirow[b]{2}{*}{$\mathrm{t}$} & \multirow[b]{2}{*}{ Sig. } & \multicolumn{2}{|c|}{ Collinearity Statistics } \\
\hline & $\overline{\mathrm{B}}$ & Std. Error & & & & Tolerance & VIF \\
\hline 1 (Constant) & 1.679 & 8.397 & & .200 & .842 & & \\
\hline ROE & -40.018 & 11.148 & -.334 & -3.590 & .001 & .612 & 1.634 \\
\hline ROE Growth Rate & -1.393 & 2.297 & -.083 & -.606 & .546 & .280 & 3.570 \\
\hline EPS Growth Rate & -1.322 & 2.417 & -.094 & -.547 & .586 & .181 & 5.510 \\
\hline DPO Ratio & 1.959 & 2.002 & .088 & .978 & .331 & .650 & 1.539 \\
\hline PBV Ratio & 4.098 & .604 & .601 & 6.786 & .000 & .676 & 1.479 \\
\hline Net Income Growth Rate & 2.427 & 2.471 & .166 & .982 & .329 & .187 & 5.355 \\
\hline PSE index & .001 & .000 & .336 & 2.854 & .006 & .382 & 2.615 \\
\hline Inflation Rate & .035 & .892 & .009 & .040 & .968 & .095 & 10.3 \\
\hline GDP Growth Rate & -.057 & .383 & -.014 & -.148 & .883 & .633 & 1.581 \\
\hline Interest Rate & -.092 & .755 & -.022 & -.122 & .904 & .162 & 6.189 \\
\hline
\end{tabular}

a. Dependent Variable: PER

Appendix 3: Mahalanobis Distance Test for Outliers

One outlier was found in the Mahalonobis distance test: Bank 4 for 2010 with Prob_MAH of 0.0003. Values of Prob_MAH that are less than 0.001 are advised to be removed from the data set prior to running the inferential analysis (Statistics Solutions). This was removed in the final data set for the multiple regression analysis 